\title{
Under-age marital childbirth in north-west Nigeria: implications for child health.
}

\author{
Olatunji Alabi ${ }^{1}$, Olusola Omisakin ${ }^{1}$ \& Adeola Alabi ${ }^{2}$ \\ ${ }^{1}$ Department of Demography and Social Statistics, Federal University, \\ Birnin Kebbi, Kebbi State, Nigeria. \\ ${ }^{2}$ NANA Women and Girls Empowerment Initiative, Adolescent Girls Initiative \\ (AGI) programme, \\ Kebbi State Office, Kebbi State, Nigeria \\ E-mail: yomistorii@yahoo.com
}

\begin{abstract}
Context/Background: Under-age marital birth is high in northern Nigeria. We explore the association between under-age marital childbirth and child health indicators in north-west Nigeria.

Data source and Methods: Analysing NDHS 2013 data of 9,01I currently married women in northwest Nigeria, with at least a childbirth in the 5 years preceding the survey, we explored the implications of maternal age at first birth for child health outcomes (anthropometric measures and child survival).

Results: The lowest age at birth in the region was 12 years. Binary logistics regression shows that odds of child survival was highest among mothers aged 18 years and above at first childbirth by $52 \%(\mathrm{Cl}$ : I.I7-I.97; p-value < 0.0I). Finding suggests that poor child anthropometric outcomes is not associated with under-age childbirth but other factors such as women education and wealth status in the study area.

Conclusion: Early childbirth prevention interventions aimed at abrogating child marriages and promoting girl child education are needed in the region.
\end{abstract}

Keywords: Child health; under-age birth; child marriage; girl child education; North-west Nigeria; NDHS.

\section{Introduction}

Globally, adolescent pregnancy and childbearing is generally viewed as detrimental to mothers (socially and physiologically) and their infants' health. Adolescent births, which is defined as births to married adolescents aged less than 15 years in this study is a major public health concerns especially in the developing countries. An estimated 16 million adolescents (aged 15-19 years) give birth globally each year (Holness, 2015). Although, adolescent birth rates have declined, differences exist across world regions. For instance, among the developed countries, United States of America have the highest proportion of adolescent pregnancy rates (Sedgh et al., 2015). Further, adolescent birth rate was highest in sub-Saharan Africa and lowest in the Western Europe/Central Asia region as at year 2012 (Santelli et al., 2017). Global concern on the high rate of adolescent births is highlighted in its choice as indicators of health and well-being within the Millennium Development Goals (MDGs) and recently, within the Sustainable Development Goals (SDGs) (Holness, 20I5).
Generally, births to teenage mothers in sub-Saharan Africa countries accounted for more than half of total births in this region to the tune of estimated 101 births per 1,000 women aged 15-19 (Odimegwu and Mkwananzi, 2016). However, within sub-Saharan Africa countries, there have been a mixed findings on the trends of adolescent pregnancies. Adolescent pregnancy decreased in East Africa, stabilized in West Africa and increased slightly in Southern Africa between 1992-20II (Odimegwu and Mkwananzi, 2016). Further, Taffa and Obare (20I7) found higher proportion of teenage pregnancy in Ethiopia with its attendant consequences of high home deliveries among teenage mothers compared to adult mothers. Odimegwu and Mkwananzi (2016) posited that $93 \%$ of the world countries whose 20-24 years olds gave birth before 18 years were in sub-Saharan Africa.

In Nigeria, measures of early child birth remains high with 5 percent of women having their first child birth before age 15 years (Malé and Wodon, 2016, Galadanci et al., 2007, Adebowale et al., 2016). The prevalence of early child birth have been identified as a driver for poor maternal and child health indices in 
Nigeria in general and northern Nigeria in particular (Finlay et al., 2017, Kana et al., 2015). There is regional differential in maternal and child health $(\mathrm{MCH})$ indicators in Nigeria with Northern region and northwest in particular being the region with the poorest maternal and child health outcomes (Fapohunda et al., 2017, Alabi et al., 2017). For instance, childhood mortality rate was as high as 105 deaths per I,000 live births in the northwest (National Population Commission (NPC) [Nigeria] and ICF International, 20I4). A typical northern Nigeria has pronounced rural poverty; gender segregation; cultural taboos against premarital sex; strict religious adherence and patriarchal predisposition for controlling female sexuality (Sampson, 2016, Mark and Asheazi, 2016). Recently, the region was characterized by insurgency and the peak of it was the kidnapping of school age girls by insurgents. The insurgencies in the region have further rendered the region more impoverished and worsened the low girl child education rate (Ugwumba and Odom, 2015, Amusan and Ejoke, 2017). Anecdotal evidence suggests that most of these girls were forcefully married away by the insurgents and thereby exposed them to the risk of child bearing at a rather too early age.

Most studies on adolescent pregnancy and child birth have focused on unmarried adolescents, adolescents in schools (both secondary and higher institution of learning) and out-of-school adolescents among others. This have resulted in limited knowledge about the levels of adolescent pregnancy and childbirth and its consequences on the health indicators of both the young mothers and their infants. The marital status of these young mothers tends to shield them from the research lens of scholars especially in developing countries like Nigeria where marriage is early and nearly universal (Clark et al., 2017). However, few studies that examined this have identified social and reproductive health consequences- including HIV/AIDS due mostly to inability to negotiate safer sex with partners as a result of age-gap between the partners (Koski et al., 2017).

Most adolescent pregnancy and childbearing in northern Nigeria occurred within marital union unlike in southern Nigeria (James, 2017). Early marriage is commonly practiced in the region and various scholars (Titus et al., 2016, Braimah, 2014, Adedokun et al., 2016, Ajala, 2014) have identified reasons ranging from poverty, preservation of virginity, cultural, socio-economic and insecurity among others. According to a report, almost 50 percent of girls were married at age 15 in northwest Nigeria and 78 percent married at age 18-23 (Population council, 2012 as cited in (Sulaiman, 2016). The consequence of early marriage are not only borne by the girls and their children, but also by the communities (PreslerMarshall and Jones, 2017). Moreso, this practice informed different approach towards addressing adolescent sexual and reproductive health between adolescents in the northern and southern Nigeria. For instance, interventions on safe abortion might not be effective in the north as it will be in southern Nigeria. Thus, we hypothesized that findings from the study will help inform effective interventions that are evidenced-based in northern Nigeria and similar settings.

Despite the awareness of the consequences of child marriage and child birth practices in the region, it remains prevalent. Thus, $72 \%$ of females in northwest region have ever married and $44.8 \%$ of females in the region, have never attended school (NPC, 2006). Curiously, research on the implications of child marriage for child health outcomes in the region is not common. We opined that the high proportion of marital adolescent pregnancy and child birth may be an important driver of the poor child health indicators in northern Nigeria. For instance, about 25 percent of the children in northern Nigeria were stunted with north-west having the highest proportion of stunted children (National Population Commission (NPC) [Nigeria] and ICF International, 20I4). Highest proportion of children whose size at birth was "very small were from northern Nigeria and, north-east and north-west in particular. Study have found out that children whose mothers are thin have the highest level of stunting (National Population Commission (NPC) [Nigeria] and ICF International, 2014).

Thus, in order to improve on the poor $\mathrm{MCH}$ indicators, it is important to examine the implications of marital adolescent pregnancy and child birth (i.e., under age pregnancy and child birth occurring within wedlock) on the child health outcomes among married adolescent. This study therefore, focused on the effect of early exposure to childbearing (defined as births to women $<15$ years) on child health outcomes in north-west Nigeria. This study is timely as Nigeria strategizes towards achieving goal's targets I, 2 and 7 of the third Sustainable Development Goals (SDGs).

\section{Literature review}

Every pregnancy carries its risk. However, births that are closely spaced, multiple births, births to young women usually below the age of eighteen and births to women after thirty-five years are generally referred to as high risk births. It has been documented in the literature that factors like age and overall health status can affect a woman's chances of experiencing complications during pregnancy 
(Sharma et al., 2013). Children born to teenage mothers are more likely to be delivered prematurely, have a low birth weight, develop placenta previa, and experience pregnancy-induced hypertension and so on due to underdeveloped pelvis, nutritional deficiencies, and high blood pressure among others (Witwit, 20I5).

Furthermore, the challenge of teenage pregnancy is more worrisome in developing countries where the health infrastructure remains inadequate to attend to most of the challenges associated with such birth. An estimated 21 million girls aged $15-19$ years, and 2 million girls under age 15 years become pregnant every year in developing countries while approximately 2.5 million girls under 16 years give birth each year in the region (WHO, 20I4). These births were associated with higher risks of eclampsia, puerperal endometritis, and systemic infections when compared with births to older women (WHO, 20I4, Ganchimeg et al., 2014). For instance, in a study in Kenya, it was found that children of under-age mothers dies more compared to older mothers' (Taffa, 2003). Similarly, LeGrand and Mbacké (1993) found a significant association between teenage pregnancy and lower birth weights and higher mortality in a study in Mali and Burkina Faso. However, while few studies (Taffa and Obare, 2017, Fall et al., 2015) found that poor child health outcomes was not influenced by maternal age at first birth but other factors mostly socio-economic empowerment of the mothers, (Finlay et al., 201 I) opined that both biological and social mechanisms explained the poor child health outcomes among under-age mothers.

In Nigeria, studies have linked poor child health outcomes to teenage pregnancy (Ezegwui et al., 20I2, Onoh et al., 20|4). The ill-equipped health facilities and the general poor health system also contributed to the immensity of the challenge of teenage pregnancy in Nigeria. This became more challenging where girl child marriage is legally recognized like in northern Nigeria and thus low girl child education rate. This act of child marriage have been inseparably linked to early child bearing. Thus, early childbearing has been identified as a risk factor of obstructed labour and cause of obstetric fistula
(Nwauche, 2015, Daru et al., 20II). Infact, Amodu (20/6) opined that the obstetric fistula policy in Nigeria cannot be implemented as long as child marriage exists. Other studies in Nigeria have explored the association between maternal age at first birth and under-five mortality (Titilayo et al., 2009, Oyefara, 2013). Titilayo et al. (2009) found high under-five mortality among young mothers and also opined that education is a predictor of under-five mortality among them. Similarly, Oyefara (2013) found significantly higher number of childhood mortality among Yoruba women whose age at birth were less than 20 years.

However, there was paucity of literature in northern Nigeria examining the association between maternal age at first birth and child health outcome. This may not be unconnected with the legal approval of child marriages in the region. Few studies in this regards Adedokun et al. (2016) have also recognized the negative implications of early childbirth on child health outcome. They found greater likelihood of delivery complications among younger mothers relative to older ones. This study contribute to knowledge by exploring empirically, the implications of under-age marital childbirth for child health in north-west Nigeria.

\section{Data and research methods \\ Study setting}

This study analyzed nationally representative data for north-west Nigeria. There are seven states in the region: Sokoto, Kebbi Zamfara, Jigawa, Katsina, Kano and Kaduna. States in the region were among the states with the highest rates of child marriages (see fig I). Also, maternal and child health outcomes were generally poor. Most communities within the States were characterized by extreme rural poverty, food crisis and famine; acute/chronic malnutrition resulting in wasting and stunting in children under five years; high level of illiteracy especially among women and sub-optimal infrastructures. For instance, Kebbi, Sokoto and Zamfara States were ranked 36th, 34th and 30th on the literacy rate by States and has one of the lowest enrollment, retention and completion rates for girl child education in Nigeria (NPC, 2006). 


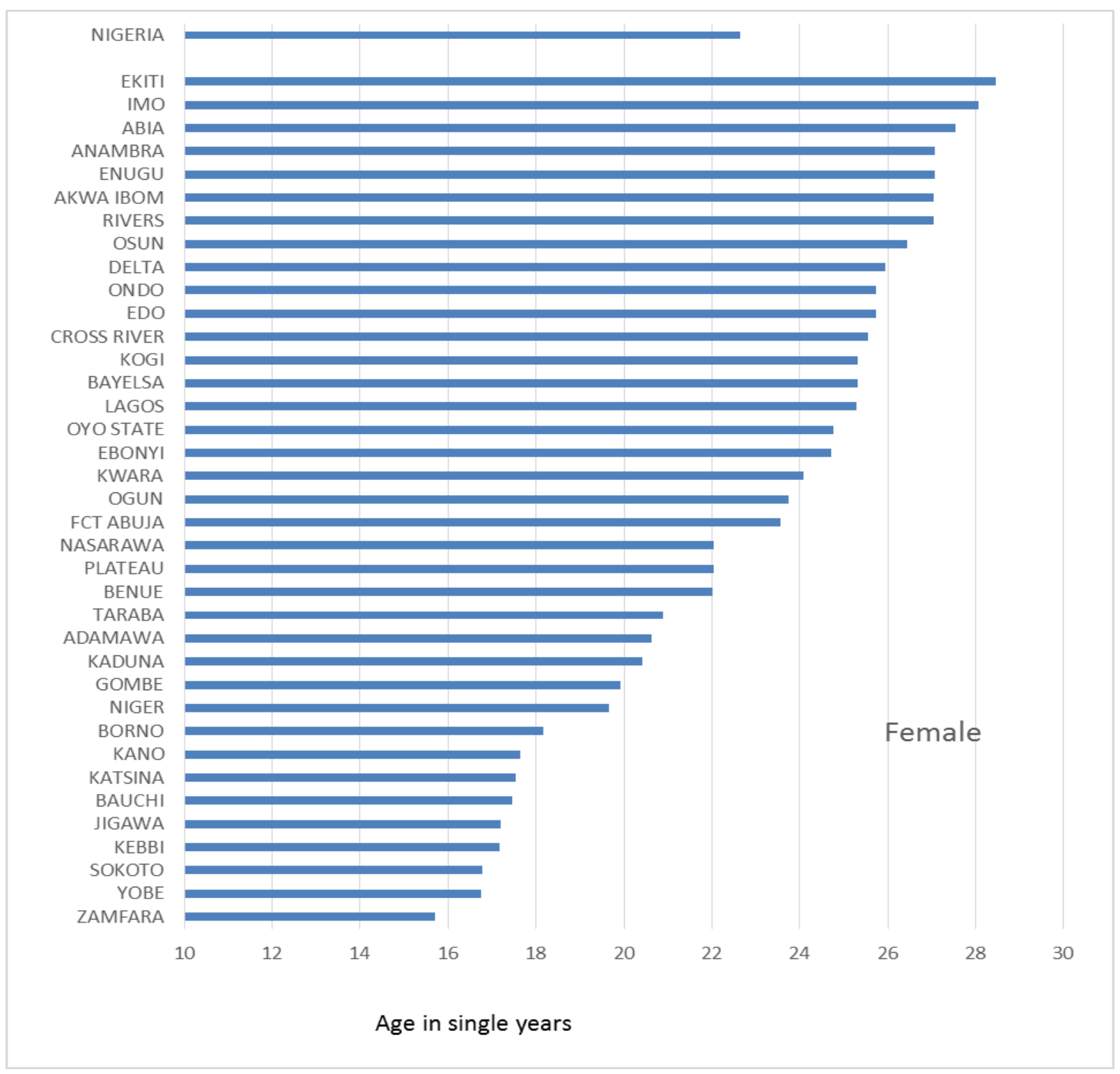

Source: Nigeria 2006 National Population and Housing Census

Fig I: Mean Age at Ist Marriage, Nigeria.

\section{Data collection}

Data for 2013 NDHS individual women recode was collected from all the 36 States and Federal Capita Territory (FCT) Abuja. . In the 2013 NDHS, the sample was designed to provide population and health indicator estimates at the national, zonal, and state levels. However, data for the study was restricted to north-west region. The primary sampling unit (PSU), regarded as a cluster for the survey was defined on the basis of Enumeration Areas (EAs). The survey used the 2006 Population Census enumeration areas as a sampling frame for the list of enumeration areas (EAs) prepared for the 2006 Population Census of the Federal Republic of Nigeria, provided by the National Population Commission.

Specifically, data collected on fertility levels, marriage, age at first birth, child anthropometric measures and child alive or dead, were analyzed for

the region. The target groups were currently married women with at least one child birth in the 5year preceding the survey in the region. The sample design allowed for specific indicators to be calculated for each of the six zones, 36 states, and the Federal Capital Territory, Abuja (National Population Commission (NPC) [Nigeria] and ICF International, 2014).

Implications of under-age marital child birth for child health outcomes was explored. Child health was measured using child's anthropometric measures like stunting, wasting and underweight and whether child was alive or dead. Weighting factors provided by Measure DHS was used in order to adjust for the effects of oversampling of some sections of the population (National Population Commission (NPC) [Nigeria] and ICF International, 20I4). Details of sampling procedure and data collection process have been documented elsewhere (National Population Commission (NPC) [Nigeria] and ICF International, 2014). 


\section{Variable measurements}

Variables used in this paper were selected based on empirical and theoretical evidence from similar studies of association between the dependent and explanatory variables (Oyefara, 2013, Taffa and Obare, 2017). Child health outcomes is the dependent variable and was measured as: child alive or dead, stunting, underweight and wasting. In the survey data, survival status of the children was captured by asking the women whether child is alive or dead $(0=$ dead; I = alive). Data on nutritional status of children was obtained using the anthropometric indices: height-for-age, weight-forage and weight-for-height standard deviations. The measures were derived from the Child Growth Standards recommended by the World Health Organisation (WHO) for assessing the physical growth and development of child up to age 5 years (Measure, 20/2). In this study, the height-for-age is recoded as stunting (less than $-2=0 ;-2$ and above $=$ I), weight-for-age is recoded as underweight (less than $-2=0 ;-2$ and above $=1$ ), while weight-forheight is recoded as wasting (less than $-2=0 ;-2$ and above = 1). Maternal age at first birth was measured in single years in the survey. We recoded the single ages into categorical variables as < I5years, 15-17 years and 18 years and above. We controlled for selected covariates such as place of residence $(I=$ urban; $2=$ rural $)$, highest level of education $(0=$ no education; 1 = primary; 2 = secondary; $3=$ higher), wealth status ( $I=$ poor; $2=$ average; $3=$ rich $)$ and employment status ( $I=$ not working; $2=$ working). Test of multicollinearity was conducted for the model and variables found to be highly correlated were dropped in the final model

\section{Analysis}

Analysis focused on married women of reproductive age 15-49 in the study area. However, since the objective of the study was to assess the implication of
Under-age marital birth for child health outcomes, the analysis excluded women who are yet to experience a child birth. The sample size was restricted to $901 \mathrm{l}$ currently married women of reproductive age who have had at least a child prior to the date of conducting the survey in the region.

The data was processed using Stata software and analyses were in three stages. Descriptive analysis of the weighted variables was done using percentages of the selected variables. Chi square (goodness of fit) test of association between measures of child health outcomes and maternal age at birth was done at the bivariate level of the analysis. Binary logistic regression was employed to address the main objective of the paper at the multivariate level of the analysis. Unadjusted and adjusted models explaining the effects of maternal age at birth and sociodemographic factors on child health outcomes were fitted.

\section{Results}

Socio-demographic profile of respondents

Table I shows the descriptive analysis of the respondents' socio-demographic characteristics. Among the respondents, almost 13\% of the women gave birth at ages less than 15 years while, $43.37 \%$ and $43.73 \%$ of them were aged $15-17$ years and 18 years and above respectively at first birth. In terms of distribution by level of education, majority $(76.96 \%)$ of the respondents had no education while, less than $2 \%$ of the respondents had higher education. About $69 \%$ of the respondents were from 'poor' households. Less than two-third of the women were employed.

Analysing data on child health outcomes, majority $(91 \%)$ of the women reported that the index birth survived. More than half (59\%) of the women reported that the index child was stunted while, $63 \%$ and $50 \%$ of the women reported that the index child was underweight and wasted respectively.

Table I: Distribution of respondents' socio-demographic profile

\begin{tabular}{|l|l|l|l|}
\hline Variable & Category & Frequency (N) & Percentage (\%) \\
\hline $\begin{array}{l}\text { Socio-economic } \\
\text { variables }\end{array}$ & & & \\
\hline $\begin{array}{l}\text { Maternal age at It birth } \\
\text { (years) }\end{array}$ & $<15$ & 1162 & 12.90 \\
\hline & $15-17$ & 3908 & 43.37 \\
\hline & $18+$ & 3941 & 43.73 \\
\hline & Total & 9011 & 100.00 \\
\hline Place of residence & Urban & 2149 & 23.84 \\
\hline
\end{tabular}


African Population Studies Vol 32, No. 3, Dec. 2018

\begin{tabular}{|c|c|c|c|}
\hline & Rural & 6863 & 76.16 \\
\hline & Total & 9011 & 100.00 \\
\hline \multirow[t]{5}{*}{ Highest educational level } & No education & 6935 & 76.96 \\
\hline & Primary & 1031 & 11.44 \\
\hline & Secondary & 901 & 10.00 \\
\hline & Higher & 144 & 1.60 \\
\hline & Total & 9011 & 100.00 \\
\hline \multirow[t]{4}{*}{ Wealth status } & Poor & 6184 & 68.63 \\
\hline & Medium & 1295 & 14.37 \\
\hline & Rich & 1532 & 17.00 \\
\hline & Total & 9011 & 100.00 \\
\hline \multirow[t]{3}{*}{ Employment status } & Not working & 3166 & 35.30 \\
\hline & Working & 5802 & 64.70 \\
\hline & Total & 8968 & 100.00 \\
\hline \multicolumn{4}{|l|}{ Child health outcomes } \\
\hline \multirow[t]{3}{*}{ Survival status of child } & Dead & 820 & 9.10 \\
\hline & Alive & 8191 & 90.90 \\
\hline & Total & 9011 & 100.00 \\
\hline \multirow{3}{*}{$\begin{array}{l}\text { Stunting } \\
\text { (height-for-age < -2) }\end{array}$} & No & 3164 & 40.98 \\
\hline & Yes & 4556 & 59.02 \\
\hline & Total & 7720 & 100.00 \\
\hline \multirow{3}{*}{$\begin{array}{l}\text { Underweight (weight-for- } \\
\text { age }<-2 \text { ) }\end{array}$} & No & 2851 & 36.92 \\
\hline & Yes & 4870 & 63.08 \\
\hline & Total & 7720 & 100.00 \\
\hline \multirow{3}{*}{$\begin{array}{ll}\text { Wasting } & \text { (weight-for- } \\
\text { height) }\end{array}$} & No & 3887 & 50.35 \\
\hline & Yes & 3833 & 49.65 \\
\hline & Total & 7720 & 100.00 \\
\hline
\end{tabular}

NDHS, 2013

Association between under-age marital child birth and child health outcomes, Northwest Nigeria.

Association between under-age marital birth and child health outcomes as reported by the women is presented in Table 2. The child health outcomes varied by maternal age at first birth. For instance, under-age mothers ( $<15$ years) reported more child deaths (I2.04\%) than mothers aged I5- I 7 years and 18 years and above at first birth respectively. On the other hand, the under-age mothers reported lower incidence of child stunting, underweight and wasting compared to mothers aged $15-17$ years and mothers aged 18 years and above at first childbirth. The chisquare and associated probability values show significant associations between maternal age at first birth and child health outcomes. 
Table 2: Distribution of child health outcomes by maternal age at first birth, NDHS, 2013

\begin{tabular}{|c|c|c|c|c|c|}
\hline \multirow[b]{2}{*}{ Variable } & \multirow[b]{2}{*}{ Category } & \multicolumn{3}{|c|}{ Maternal Age at I ${ }^{\text {st }}$ Birth (years) } & \multirow[b]{2}{*}{ Chi-square } \\
\hline & & $\begin{array}{l}<15 \\
N(\%) \\
\end{array}$ & $\begin{array}{l}15-17 \\
N(\%)\end{array}$ & $\begin{array}{l}18+ \\
N(\%)\end{array}$ & \\
\hline \multirow[t]{3}{*}{ Child is alive } & No & $140(12.04)$ & $355(9.08)$ & $326(8.26)$ & $5.0973 * *$ \\
\hline & Yes & $1022(87.96)$ & $3553(90.92)$ & $3615(9 \mid .74)$ & \\
\hline & Total & $1162(100.0)$ & $3908(100.0)$ & $394 \mid(100.0)$ & \\
\hline \multirow{3}{*}{$\begin{array}{l}\text { Stunting } \\
\text { (height-for-age < } \\
-2 \text { ) }\end{array}$} & No & $48 I(47.32)$ & $1313(39.02)$ & I370 (4I.03) & $6.8247 * *$ \\
\hline & Yes & $535(52.68)$ & $2052(60.98)$ & $1969(58.97)$ & \\
\hline & Total & $1016(100.0)$ & $3365(100.0)$ & $3340(100.0)$ & \\
\hline \multirow{3}{*}{$\begin{array}{l}\text { Underweight } \\
\text { (weight-for-age < } \\
-2 \text { ) }\end{array}$} & No & $455(44.77)$ & $1185(35.22)$ & $121 \mid(36.26)$ & $8.5498 * * * *$ \\
\hline & Yes & $56 \mid(55.23)$ & $2180(64.78)$ & $2129(63.74)$ & \\
\hline & Total & $1016(100.0)$ & $3365(100.0)$ & $3340(100.0)$ & \\
\hline \multirow{3}{*}{$\begin{array}{l}\text { Wasting (weight- } \\
\text { for-height) }\end{array}$} & No & $598(58.86)$ & $1673(49.7 I)$ & $1616(48.4)$ & $8.7765^{* * * *}$ \\
\hline & Yes & $4 \mid 8(4|| 4)$. & $1692(50.29)$ & I $723(5 \mid .6)$ & \\
\hline & Total & $1016(100.0)$ & $3365(100.0)$ & $3340(100.0)$ & \\
\hline
\end{tabular}

Implications of maternal age at first childbirth and sociodemographic characteristics for child health outcomes, Northwest Nigeria.

Table 3 (Model I) shows that maternal age at first birth is positively associated with child survival among the respondents. The results indicate that the odds of child survival was greater among mothers aged I5-I7 years at first childbirth by $(\mathrm{OR}=1.37$; $\mathrm{Cl}$ : I.06-I.78; $\mathrm{p}$-value $<0.05)$ and mothers aged 18 years and above at first childbirth by $(\mathrm{OR}=1.52 ; \mathrm{Cl}$ : I. I7-I.97; $\mathrm{p}$-value $<0.0 \mathrm{I})$ compared to the underage mothers. In other words, the underage mothers maybe expected to experience more child deaths compared to aged 15-17 years and 18years and above respectively.

However, the results further indicate that underage mothers stand lower chances of experiencing poor child nutritional status than the older mothers. The odds of child stunting was greater among mothers aged 15-17 years at first childbirth by $40 \%(\mathrm{Cl}$ : I.I 7 -I.69; p-value $<0.00 \mathrm{I})$ and mothers aged 18 years and above at first childbirth by $29 \%(\mathrm{Cl}$ : I.09-I.53; p-value $<0.00 \mathrm{I})$ compared to the underage mothers. The odds of child being underweight was also greater among mothers aged $15-17$ years at first childbirth by
$(\mathrm{OR}=\mathrm{I} .49 ; \mathrm{Cl}: \mathrm{I} .23-\mathrm{I} .8 \mathrm{I} ; \mathrm{p}$-value $<0.00 \mathrm{I})$ and mothers aged 18 years and above at first childbirth by $(\mathrm{OR}=1.42 ; \mathrm{Cl}$ : I.I6-I.74; p-value < 0.0I) compared to the underage mothers. Likewise, the odds of child wasting was greater among mothers aged 15-17 years at first childbirth by $45 \%(\mathrm{Cl}$ : I.19-I.76; $\mathrm{p}$ value $<0.00 \mathrm{I})$ and mothers aged 18 years and above at first childbirth by $53 \%$ (Cl: I.23-I.90; p-value < 0.01 ) compared to the underage mothers.

Furthermore, model 2 (Adjusted model for sociodemographic variable) (Table 3), maternal age at first birth remained significantly associated with the child survival (though with reduced odds). Also, in the adjusted model, the odds of child survival was significantly higher among women with secondary education and women from rich households. For instance, odds of child survival was $95 \%$ greater among currently married women who had secondary education ( $\mathrm{Cl}$ : I.05-3.60; p-value < 0.05) compared to those who had no education. Further, women who are from rich households were $63 \%$ more likely to have survived child ( $\mathrm{Cl}$ : I.0I-2.64; $\mathrm{p}$-value < 0.05) compared to those who are from poor households. 
African Population Studies Vol 32, No. 3, Dec. 2018

Table 3: Binary logistic regression of the effects of maternal age at first birth and socio-demographic factors on child health outcomes, NDHS, 20I3

\begin{tabular}{|c|c|c|c|c|c|c|c|c|}
\hline \multirow{2}{*}{$\begin{array}{l}\text { Characteristic } \\
\mathrm{s}\end{array}$} & \multicolumn{4}{|c|}{ Model I } & \multicolumn{4}{|c|}{ Model 2} \\
\hline & $\begin{array}{l}\text { Child } \\
\text { alive }\end{array}$ & $\begin{array}{l}\text { Stuntin } \\
\mathrm{g}\end{array}$ & $\begin{array}{l}\text { Underweigh } \\
\text { t }\end{array}$ & $\begin{array}{l}\text { Wastin } \\
\mathrm{g}\end{array}$ & $\begin{array}{l}\text { Child } \\
\text { alive }\end{array}$ & $\begin{array}{l}\text { Stuntin } \\
\mathrm{g}\end{array}$ & $\begin{array}{l}\text { Underweigh } \\
\text { t }\end{array}$ & $\begin{array}{l}\text { Wastin } \\
\mathbf{g}\end{array}$ \\
\hline & $\begin{array}{l}\text { Yes } \\
\text { (OR) } \\
{[95} \\
\% \\
\mathrm{Cl}]\end{array}$ & $\begin{array}{l}\text { Yes } \\
(\mathrm{OR}) \\
{[95 \%} \\
\mathrm{Cl}]\end{array}$ & $\begin{array}{l}\text { Yes (OR) } \\
{[95 \% \mathrm{Cl}]}\end{array}$ & $\begin{array}{l}\text { Yes } \\
\text { (OR) } \\
{[95 \%} \\
\mathrm{Cl}]\end{array}$ & $\begin{array}{l}\text { Yes } \\
\text { (OR) } \\
{[95} \\
\% \\
\mathrm{Cl}]\end{array}$ & $\begin{array}{l}\text { Yes } \\
\text { (OR) } \\
{[95 \%} \\
\mathrm{Cl}]\end{array}$ & $\begin{array}{l}\text { Yes (OR) } \\
{[95 \% \mathrm{Cl}]}\end{array}$ & $\begin{array}{l}\text { Yes } \\
\text { (OR) } \\
{[95 \%} \\
\mathrm{Cl}]\end{array}$ \\
\hline \multicolumn{9}{|l|}{$\begin{array}{l}\text { Age at first } \\
\text { birth }\end{array}$} \\
\hline$<$ I5years & I & I & I & I & 1 & I & I & I \\
\hline $15-17$ years & $\begin{array}{l}1.37 * \\
{[1.06-} \\
1.78]\end{array}$ & $\begin{array}{l}1.40 \text { *** } \\
{[1.17-} \\
1.69]\end{array}$ & $\begin{array}{l}.49 * * * * \\
{[1.23-1.81]}\end{array}$ & $\begin{array}{l}1.45 * * * \\
{[1.19-} \\
1.76]\end{array}$ & $\begin{array}{l}1.34 * \\
{[1.04-} \\
I .73]\end{array}$ & $\begin{array}{l}\text { I.4I }{ }^{*} * * \\
{[1.17-} \\
1.69]\end{array}$ & $\begin{array}{l}\text { I.49**** } \\
{[1.22-1.82]}\end{array}$ & $\begin{array}{l}\text { I.44*** } \\
{[1.18-} \\
\text { I.75] }\end{array}$ \\
\hline 18 years + & $\begin{array}{l}1.52 * * \\
{[1.17-} \\
1.97]\end{array}$ & $\begin{array}{l}1.29 * * * * \\
{[1.09-} \\
1.53]\end{array}$ & $\begin{array}{l}1.42 * * * 1.16- \\
1.74]\end{array}$ & $\begin{array}{l}1.53 * * * \\
{[1.23-} \\
1.90]\end{array}$ & $\begin{array}{l}1.36 * \\
{[1.05-} \\
1.76]\end{array}$ & $\begin{array}{l}1.32 * * \\
{[1.11-} \\
1.57]\end{array}$ & $\begin{array}{l}.44 * * * 6 \\
{[1.18-1.76]}\end{array}$ & $\begin{array}{l}1.48 * * * \\
{[1.19-} \\
1.82]\end{array}$ \\
\hline \multicolumn{9}{|l|}{ Residence } \\
\hline Rural & & & & & I & I & I & I \\
\hline Urban & & & & & $\begin{array}{l}0.97 \\
{[0.64-} \\
1.45]\end{array}$ & $\begin{array}{l}1.20 \\
{[0.98-} \\
1.46]\end{array}$ & $\begin{array}{l}1.17 \quad[0.90- \\
1.48]\end{array}$ & $\begin{array}{l}1.06 \\
{[0.85-} \\
1.32]\end{array}$ \\
\hline \multicolumn{9}{|l|}{ Education } \\
\hline No education & & & & & I & I & I & I \\
\hline Primary & & & & & $\begin{array}{l}1.28 \\
{[0.94-} \\
1.74]\end{array}$ & $\begin{array}{l}1.16 \\
{[0.91-} \\
1.47]\end{array}$ & $\begin{array}{l}1.16 \\
1.73]\end{array}$ & $\begin{array}{l}1.12 \\
{[0.90-} \\
1.41]\end{array}$ \\
\hline Secondary & & & & & $\begin{array}{l}1.95 * \\
{[1.05-} \\
3.60]\end{array}$ & $\begin{array}{l}1.15 \\
{[0.84-} \\
1.59]\end{array}$ & $\begin{array}{l}1.30 \\
1.10]\end{array}$ & $\begin{array}{l}1.20 \\
{[0.89-} \\
1.62]\end{array}$ \\
\hline Higher & & & & & $\begin{array}{l}0.96 \\
{[0.34-} \\
2.69]\end{array}$ & $\begin{array}{l}0.67 \\
{[0.36-} \\
I .23]\end{array}$ & $\begin{array}{l}0.65 \\
1.40]\end{array}$ & $\begin{array}{l}0.73 \\
{[0.4 \mid-} \\
.28]\end{array}$ \\
\hline \multicolumn{9}{|l|}{ Wealth Status } \\
\hline Poor & & & & & 1 & 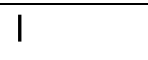 & $I$ & $I$ \\
\hline Average & & & & & $\begin{array}{l}1.17 \\
{[0.87-} \\
1.59]\end{array}$ & $\begin{array}{l}I .11 \\
{[0.92-} \\
1.35]\end{array}$ & $\begin{array}{l}1.17 \\
1.18]\end{array}$ & $\begin{array}{l}1.09 \\
{[0.90-} \\
1.33]\end{array}$ \\
\hline Rich & & & & & $1.63^{*}$ & 0.94 & $0.93 \quad[0.81-$ & 1.17 \\
\hline
\end{tabular}




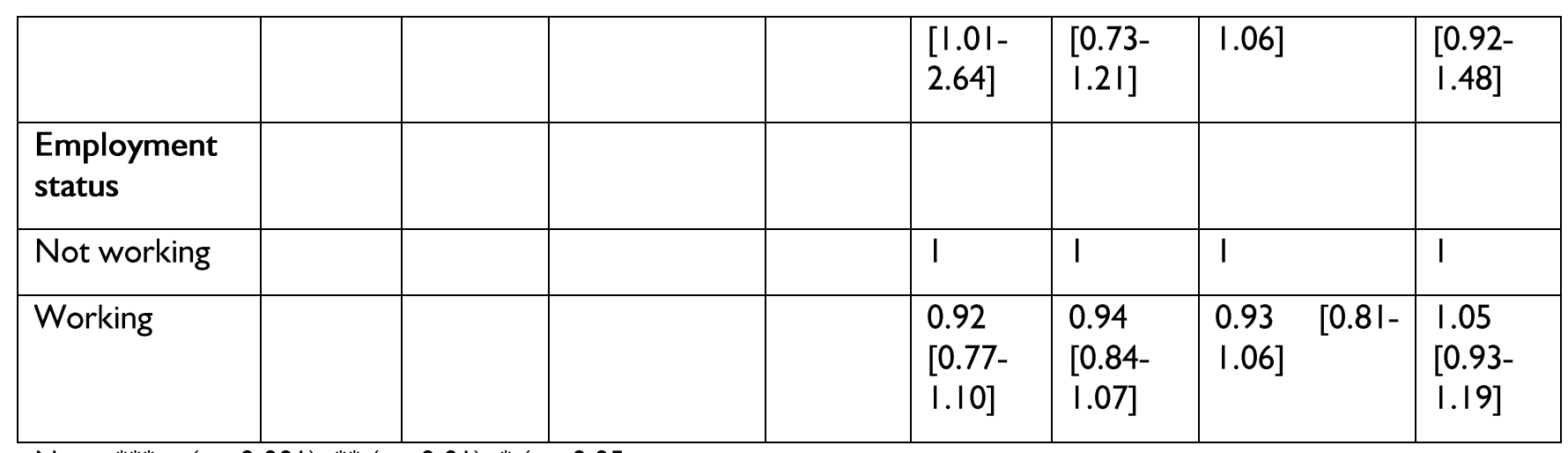

Note: ${ }^{* * *}=(p<0.00 \mathrm{I}),{ }^{* *}(\mathrm{p}<0.0 \mathrm{I}),{ }^{*}(\mathrm{p}<0.05$

\section{Discussion}

This paper set out to explore the implications of early exposure to childbearing- defined as births to married women less than fifteen years old- for child health outcomes in northwest Nigeria. The issue is of utmost importance in northwest Nigeria due to high prevalence of child marriages. We found that age at first birth was as low as 12 years in the region. Studies have explained the low age at first birth in the region on general cultural taboo on premarital sex and religious dictate (Fagbamigbe and Idemudia, 2016). This is further reinforced by low level of girl child education and general low status among women in the region. The region have the lowest women literacy rate in Nigeria and thus, low women status which have health consequences (Abubakar et al., 2017). This calls for behavioural change interventions and policy to down play marrying young girls and instead promoting girl child education especially among the rural poor in the region.

Furthermore, unadjusted odds of having stunted, underweight and wasted child was significantly higher among women with higher age at first birth compared with under-age mothers. This findings might be explained by the possibility that under-age mothers are mostly newly wedded who are often showered with a lot of care (including health care) by the spouse and family members especially during first pregnancy leading to a positive child health outcomes. The findings also agrees with the findings in similar studies which examined the association between maternal age at child birth and child health outcomes (Fall et al., 2015, Taffa and Obare, 2017). For instance, (Taffa and Obare, 2017) opined that poor child survival might be more related to poor socio-economic development of under-age mothers than their age at childbirth.

We found that mother's age at first birth was significantly associated with child being alive. Women who had under-age birth might be less physically mature themselves and this can affect the growth of the foetus. Carrying pregnancy to term requires a fully biologically developed reproductive organs which may not be the case with under age women giving birth. Thus, studies have established the implication of this on the high prevalence of Vesico Vigina Fistula (WF) in the region and high infant mortality (Daru, Kashima, Michal \& Nyango, 20II; Duru, 2016).

The findings further underscore the need for interventions abrogating child marriages especially in the region. Studies have documented the low rate of girl child education in northern Nigeria (Mercy, 2017, Adekola et al., 2016) Interventions promoting enrollment, retention and completion rate of girl child education with reproductive health component like the adolescent girl initiative programme- which focused on primary school girls- funded by the United Nations Funds for Population Activities (UNFPA) and implemented by NANA women and girl empowerment initiative currently running in two states of kebbi and Kaduna in the region, should be priotized and probably scaled up to other states in the region. Similarly, the Girls for Health (G4H) project, funded by Bill and Melinda Gates Foundation (BMGF) and implemented by the Department of Demography and Social Statistics, Federal University Brnin Kebbi, Kebbi State, should be supported by all stakeholders. The project's aims of improving girl child secondary school completion and graduation rate into health training institutions, should be supported by the state governments of the implementing states.

\section{Conclusion}

Child survival is associated with maternal age at first birth. Improved child anthropometric measures are more related to women socio-economic development rather than age at first birth. Findings from the paper calls for women empowerment and abrogation of child marriage in the region. Linked to this is the call for the improvement on the literacy level in general and girl child education in particular. 


\section{Conflict of Interest}

The authors declares that there is no conflict of interest.

\section{References}

ABUBAKAR, I. S., BABASHANI, M. \& GALADANCI, H. S. 2017. Domestic Violence among Women Living with HIV/AIDS in Kano, Northern Nigeria. African Journal of Reproductive Health, 15.

ADEBOWALE, A. S., FAGBAMIGBE, A. F. \& ADEBAYO, A. M. 2016. Regional Differences in Adolescent Childbearing in Nigeria. Journal of Population and Social Studies [JPSS], 24, I0I-I I6.

ADEDOKUN, O., ADEYEMI, O. \& DAUDA, C. 2016. Child marriage and maternal health risks among young mothers in Gombi, Adamawa State, Nigeria: implications for mortality, entitlements and freedoms. African health sciences, 16, 986999.

ADEKOLA, P. O., AKANBI, M. A. \& OLAWOLEISAAC, A. 2016. A Qualitative Assessment of the Effects of Child Marriage on Female Education and Entrepreneurship in Northeastern Nigeria. International Journal of Scientific Research in Multidisciplinary Studies ISROSET, 2, 7-I5.

AJALA, A. O. 2014. Factors associated with teenage pregnancy and fertility in Nigeria. children, 5.

ALABI, O., OYEDOKUN, O. A., DOCTOR, H. V. \& ADEDINI, S. A. 2017. Determinants of under-five mortality clustering in a health and demographic surveillance system in Zamfara State, northern Nigeria. African Population Studies, 3I.

AMODU, O. C. 2016. Obstetric Fistula Policy in Nigeria: A Critical Discourse Analysis. University of Alberta.

AMUSAN, L. \& EJOKE, U. P. 2017. The psychological trauma inflicted by Boko Haram insurgency in the North Eastern Nigeria. Aggression and violent behavior, 36, 52-59.

BRAIMAH, T. S. 20I4. Child marriage in Northern Nigeria: Section 6I of Part I of the 1999 Constitution and the protection of children against child marriage. African Human Rights Law Journal, I4, 474-488.

CLARK, S., KOSKI, A. \& SMITH-GREENAWAY, E. 2017. Recent Trends in Premarital Fertility across Sub-Saharan Africa. Studies in Family Planning, 48, 3-22.

DARU, P., KARSHIMA, J., MIKAH, S. \& NYANGO, D. 20II. The burden of vesico-vaginal fistula in north central Nigeria. Journal of the West African College of Surgeons, I, 50.

EZEGWUI, H., IKEAKO, L. \& OGBUEFI, F. 2012. Obstetric outcome of teenage pregnancies at a tertiary hospital in Enugu, Nigeria. Nigerian journal of clinical practice, I5, I47-I50.
FAGBAMIGBE, A. F. \& IDEMUDIA, E. S. 2016. Survival analysis and prognostic factors of timing of first childbirth among women in Nigeria. BMC pregnancy and childbirth, 16, 102.

FALL, C. H., SACHDEV, H. S., OSMOND, C., RESTREPO-MENDEZ, M. C., VICTORA, C., MARTORELL, R., STEIN, A. D., SINHA, S., TANDON, N. \& ADAIR, L. 20I5. Association between maternal age at childbirth and child and adult outcomes in the offspring: a prospective study in five low-income and middle-income countries (COHORTS collaboration). The Lancet Global Health, 3, e366-e377.

FAPOHUNDA, B., OROBATON, N., SHORETIRE, K. \& LAMIRI, G. 2017. Is delivery with no one present linked to other health care risks across the maternal and child health continuum in northwest zone of Nigeria? clues from the demographic and health survey. African Population Studies, 3I.

FINLAY, J. E., NORTON, M. K. \& GUEVARA, I. M. 2017. Adolescent Fertility and Child Health: The Interaction of Maternal Age, Parity and Birth Intervals in Determining Child Health Outcomes. International Journal of Child Health and Nutrition, 6, 16-33.

FINLAY, J. E., ÖZALTIN, E. \& CANNING, D. $201 \mathrm{l}$. The association of maternal age with infant mortality, child anthropometric failure, diarrhoea and anaemia for first births: evidence from 55 low-and middle-income countries. BMJ open, I, e000226.

GALADANCI, H., EJEMBI, C., ILIYASU, Z., ALAGH, B. \& UMAR, U. 2007. Maternal health in Northern Nigeria-a far cry from ideal. BJOG: An International Journal of Obstetrics \& Gynaecology, I I 4, 448-452.

GANCHIMEG, T., OTA, E., MORISAKI, N., LAOPAIBOON, M., LUMBIGANON, P., ZHANG, J., YAMDAMSUREN, B., TEMMERMAN, M., SAY, L. \& TUNÇALP, Ö. 20I4. Pregnancy and childbirth outcomes among adolescent mothers: a World Health Organization multicountry study. BJOG: An International Journal of Obstetrics \& Gynaecology, I2I, 40-48.

HOLNESS, N. 20I5. A global perspective on adolescent pregnancy. International journal of nursing practice, $21,677-681$.

JAMES, G. 2017. THE CHALLENGES OF ADOLESCENTS'SEXUAL AND REPRODUCTIVE HEALTH IN NORTHERN NIGERIA. EBSU Journal of Social Sciences and Humanities, 3.

KANA, M. A., DOCTOR, H. V., PELETEIRO, B., LUNET, N. \& BARROS, H. 2015. Maternal and child health interventions in Nigeria: a systematic 
review of published studies from 1990 to 2014 . BMC Public Health, I5, 334.

KOSKI, A., CLARK, S. \& NANDI, A. 20I7. Has Child Marriage Declined in sub-Saharan Africa? An Analysis of Trends in 31 Countries. Population and Development Review, 43, 7-29.

LEGRAND, T. K. \& MBACKÉ, C. S. 1993. Teenage pregnancy and child health in the urban Sahel. Studies in family planning, 137-I49.

MALÉ, C. \& WODON, Q. 2016. Basic profile of early childbirth in Nigeria.

MARK, M. S. \& ASHEAZI, N. R. 20I6. Mitigating the Environmental Impact of Poverty among Female Gender in Nigeria through Advocacy. International Journal of Innovative Research and Development, 5.

MEASURE, D. 2012. Standard Recode Manual for DHS 5. Calverton: USAID.

MERCY, O. 20I7. An assessment of factors militating against girl child education in Nigeria. International Journal of Advanced and Multidisciplinary Social Science, 3, 49-54.

NATIONAL POPULATION COMMISSION (NPC) [NIGERIA] \& ICF INTERNATIONAL 2014. Nigeria 2013 Demographic and Health Survey. Abuja, Nigeria, and Rockville, Maryland, USA: National Population Commission and ICF International.

NPC 2006. Population and Housing Census of the Federal Republic of Nigeria: National and State Population and Housing Tables. Federal Republic of Nigeria - Abuja: : National Population Commission (NPC), 2009.

NWAUCHE, E. S. 2015. Child marriage in Nigeria:(II) legal and (un) constitutional? African Human Rights Law Journal, I5, 42 I-432.

ODIMEGWU, C. \& MKWANANZI, S. 2016. Factors associated with teen pregnancy in sub-Saharan Africa: a multi-country cross-sectional study. African Journal of Reproductive Health, 20, 94107.

ONOH, R. C., EZEONU, P. O., ANOZIE, B. O., ESIKE, C. O. U., OBUNA, J. A., EGBUJI, C., AGWU, U. M., AGBOEZE, J. \& CHUKWUDI, I. P. 2014. Outcome of teenage pregnancy at a tertiary hospital in Abakaliki southeast Nigeria. Journal of basic and clinical reproductive sciences, 3, 22-26.

OYEFARA, J. L. 2013. Maternal age at first birth and childhood mortality in yoruba society: the case of Osun State, Nigeria. Res Humanities Soc Sci, 3, 246-254.
PRESLER-MARSHALL, E. \& JONES, N. 2017. The adolescent imperative.

SAMPSON, I. T. 2016. The dilemmas of counterbokoharamism: Debating state responses to Boko Haram terrorism in northern Nigeria. Security Journal, 29, I22-I46.

SANTELLI, J. S., SONG, X., GARBERS, S., SHARMA, V. \& VINER, R. M. 20I7. Global Trends in Adolescent Fertility, 1990-2012, in Relation to National Wealth, Income Inequalities, and Educational Expenditures. Journal of Adolescent Health, 60, I6I-I68.

SEDGH, G., FINER, L. B., BANKOLE, A., EILERS, M. A. \& SINGH, S. 2015. Adolescent pregnancy, birth, and abortion rates across countries: levels and recent trends. Journal of Adolescent Health, 56, 223-230.

SHARMA, R., BIEDENHARN, K. R., FEDOR, J. M. \& AGARWAL, A. 2013. Lifestyle factors and reproductive health: taking control of your fertility. Reproductive Biology and Endocrinology, II, 66.

SULAIMAN, K.-D. O. 2016. Islamic responses to the raging debate of child marriage in Nigeria. Ahfad Journal, 33, 29-43.

TAFFA, N. 2003. A comparison of pregnancy and child health outcomes between teenage and adult mothers in the slums of Nairobi, Kenya. International Journal of Adolescent Medicine and Health, I5, 321-330.

TAFFA, N. \& OBARE, F. 20I7. Pregnancy and child health outcomes among adolescents in Ethiopia. The Ethiopian Journal of Health Development (EJHD), I8.

TITILAYO, A., OBIYAN, M., AGUNBIADE, O. \& FASINA, F. 2009. Maternal age at birth and under5 mortality in Nigeria. East African journal of public health, $6,1 \mathrm{I}-14$.

TITUS, A. B., DADA, A. B. \& ADU, E. O. 2016. Effects of Social Habits and Girl-child Marriage on Students Academic Performance in Social Studies.

UGWUMBA, E. \& ODOM, T. 20I5. Boko Haram Insurgency: $A$ peril to achievement of education for

all in Nigeria". International Journal of Education, Learning and Development, 3.

WHO 20I4. Adolescent Pregnancy: Factsheet No 364.[Online] Available from: http://www. who. int/mediacentre/factsheets/fs364/en. Accessed.

WITWIT, S. J. 20I5. Teenage Motherhood: Maternal \& Fetal Complications. Journal of Babylon University/pure and applied science, 2, 828-842. 